\title{
Research on Financing Complexity of Small And Micro Enterprises Based on Amartya Sen Entitlement Conception
}

\author{
Jian-Ying Lou L a $^{1,}$ \\ ${ }^{1}$ Department of Economics, China University Of Geosciences Great Wall College,Baoding, China \\ a309280747@qq.com
}

Keywords: Amartya Sen entitlement; Small and micro enterprises; Financing

\begin{abstract}
To describe the financing coefficients of small and micro enterprises, this paper use price elasticity to build the concrete form of it, basing on Amartya Sen entitlement approach. According to 71 small and micro enterprises' detailed survey data, the paper set up a Log-Linear Model to calculate the financing coefficients of assets, land and revenue and draw a conclusion that there are many constraints and poor status on financing. Meanwhile, increasing the amount of credit has no effect and reforming the financial system is not obvious either. The improvement of the financing availability in SME(small and micro enterprises) is a systems engineering which needs cooperation and collaboration from related factor market reform policies.
\end{abstract}

\section{Introduction}

At present, small and micro enterprises' difficulty of financing have become the consensus of academia, government and society. There are a large number of research results emerging, majoring in how to resolve financing problems in small and medium-sized enterprises or SME and pitching mainly in financing causes and factors, which improve the plight of financing in SME from credit supply in terms of policy implication [1]. But almost all studies in an attempt to solve this problem implied the hypothesis that SEM have trouble in financing.

In general, two Indicators are used to evaluate the availability of financing, one is financing magnitude(M), the other is the proportion of financing magnitude (M) and demand (D) which can illustrate the satisfaction degree of financing requirements. Although these two Indicators can clearly explain the difficulty of financing, they still exist flaws. First one is different-sized enterprises differ fairly in financing demand, no standardized proportion can demonstrate which company could obtain the largest loan [2]. Furthermore, the cash flow and financing demand of the SEM on time series are ever-changing. Therefore, it's unadvisable to measure how well the financing is by a fixed proportions constant. The second is that these two indicators are not a good indication of the ability of financing in SME because different-sized SME or even the same scale enterprises all can't merely rely on financing magnitude to demonstrate which one is stronger. Actually, SME has trouble in financing was based on the above two indicators, but as a measure of financing capacity for this group it is insufficient [3].

Overall, the measurement of how difficult SME' financing is would seem to need more in-depth study and response. How the availability of SME' financing is? How to express and estimate SME' financing availability? Except for the influence of external finance volume, borrowing capacity which is the core elements in the development of SME is more important [4]. In that way, the basic theory of What should the theoretical basis for evaluating or estimating borrowing capacity and reflecting the difficulty of financing be like? To answer the above questions, the following passage estimates the difficulty of financing in SME through financing coefficient model in the perspective of Amartya Sen entitlement, using 71 sample enterprises' survey data from 4 province.

Financing entitlement is mapped to the availability of SME financing

Amartya Sen is famous for his analysis of the causes of famine, and his entitlement approach almost subverts the traditional view of the famine interpretation. Sen defined entitlement as following: $E_{i}$ represents the $i$-th individual's entitlement set, in the pending cases, the set of all the alternative bundles of commodities that the individual can acquire is the entitlement set; In the 
private ownership economy, $E_{i}$ depends on personal resources endowment (ownership bundle) and exchange entitlement mapping (It is the functional relation that specifies the set of commodities that the individual can dominate for each ownership bundle.). Exchange entitlement mapping can be called "E- mapping." for short.

In the context of SME' financing, entitlement approach is that SME make use of their resource endowment to exchange or acquire financing(currency). $E_{i}$ is the $i$-th SME financing on resource endowment and alternatives. SME financing depends on the resources endowment of the enterprise and exchange entitlement mapping, that is to say, the enterprise can get the function of financing through it's resource endowment. The policy attempting to increase the amount of enterprise financing while neglecting the point that the function is a complicated system which can affect SME financing may be invalid.

In fact, Sen's claim lacks an important factor, that is credit resources. Credit resources can be deposits of banks (no supervision,banks can lend freely), family's spot cash or monetary resources of other financial institutions, which can be involved in the actual operation of SME. As a consequence, it's perfect to contain credit resources in the entitlement approach.

Thus, the entitlement approach provides the more comprehensive method to inspect the availability of SME financing. In this way, the availability of SME financing become an endogenous variable including various factors. In current economy (resource endowment, financing entitlement mapping and credit resources are given), this variables needs accurate number to express. Although the SME financing's entitlement mapping function is fairly complex and difficult to quantify, the availability of SME financing is the result of the entitlement mapping. If the number which indicates the availability of SME financing can be reckoned, then this number not only includes the effect of entitlement mapping, but also evaluates the SME financing capacity accurately no longer simply.

\section{Definition of financing coefficients which were used to reflect the availability of SME financing}

This paper presents an conception of the SME financing coefficients to estimate the availability of SME financing in Amartya Sen entitlement approach. The financing coefficients refer to elasticity in economics. Elasticity is used to measure the reaction of supply or demand to the price changes, generally speaking, it contains supply, demand and price elasticity. Financing coefficients can be defined as the reaction of financing capacity to resource endowment changes.

Expression of financing coefficients:

$$
\varepsilon=\frac{x_{i}}{y} \frac{\delta y}{\delta x_{i}}
$$

Among them, $x_{i}$ is the resource endowment of the $i$-th SME and $y$ is its' financing. Replace the price in general price elasticity to resource endowment so that the coefficients can indicate the reaction of financing capacity to resource endowment changes accurately. Similarly, there are also elastic $(\varepsilon>1)$ and inelastic $(0<\varepsilon \leq 1)$ existing in SME financing coefficients. If $\varepsilon>1$, SME have a strong ability to acquire financing, deploy resource ,response quickly to the whole economic environment and operate normally no matter how the external pressure shocked. If $0<\varepsilon \leq 1$, SME is more difficult to acquire financing, deploy resource and adapt weakly to the changing environment. Such enterprises are vulnerable to the shock from outside so fragile that they may run into trouble or go bankrupt severely.

Both financing capacity determining by capital supply of SME and outside together and resource endowment remaining SME owned are considered in SME financing coefficients;hence SME financing coefficient embrace internal and external determinants. On account of the complexity of external determinants, some recessive factor are hard to search and classified into SME' entitlement mapping function. As a whole, SME financing coefficient is a overall indicator combining resource 
endowment, financing capacity and financing factors from outside. As a consequence of intersection, it may reflect the availability of SME financing precisely and the condition of financing entitlement synthetically.

\section{The estimating model of SME financing coefficient}

In the case of traditional mortgage loan, land is a significant collateral. Financial institutions prefers to land mortgage lending and enterprises are also obtain loans easily through it. With the development of chattel mortgage lending technology, enterprises could raise a mortgage on movable property to get loans. Financial institutions research focus on corporation business status so as to make sales revenues to be a vital lending observational index. Sales revenues, the significant indicator of observing corporation cash flow, if favorable, could persuade the financial institutions as well as the folk to offer loans. Therefore, this article mainly study the influence of land, asset and revenues to SME financing capacity and estimate financing coefficient from the angle of "entitlement" mapped at the three resource endowment.

The double-log model of SME financing and financing coefficient is built as follows:

$$
\begin{gathered}
y_{i}=\beta_{0}+\beta_{1} x_{i, 1}+\beta_{2} x_{i, 2}+\beta_{3} x_{i, 3}+\mu_{i} \\
\ln y_{i}=\beta_{0}+\beta_{1} \ln x_{i, 1}+\beta_{2} \ln x_{i, 2}+\beta_{3} \ln x_{i, 3}+\mu_{i}
\end{gathered}
$$

Among the equations, $y_{i}$ is the ith SME financing, $x_{i, 1}, x_{i, 2}$ and $x_{i, 3}$ denotes asset, revenues and land respectively. Equation (2) is model 1 in order to estimate the effect of various factors of production to financing capacity. Equation (3) is model 2 for the sake of estimating SME financing coefficients such as $\beta_{1}$, the asset's financing coefficient. Take partial derivative of (3) with respect to $x_{i, 1}, \beta_{1}=\frac{x_{i, 1}}{y_{i}} \frac{\delta y_{i}}{\delta x_{i, 1}}$,in the same way, $\beta_{2}, \beta_{3}$ is the revenues and land financing coefficient separately.

Financing coefficients contain abundant information and each one roughly reflects the extent as well as difficulty of the SME financing from external economic environment relying on certain resource endowment. At the same time, financing coefficient offers a fairly accurate and quantitative solution, which become a gist for further study about the widely discussed SME financing problems.

\section{The result of regression model and correlation analysis}

In this paper, the data was obtained from the group of rural finance and investment research center in China Agricultural University focused on SME in Jan, 2013. The issue is designed to research the rural credit cooperative (RCC) performance on reform and the credit service supplied for the farmer and SME. And the sample were distributed in Shandong(16), Henan(19), Anhui (18), and Yunnan (18), totally including 71 enterprises.

This article utilizes the Eviews 6 for model regression analysis as shown in table 1. Taking the heteroscedasticity problem into account, this paper carries White testing for the models. The null hypothesis that these two models may exist heteroscedasticity problem was rejected due to the highly significance of the White testing (at significance level 95\%). Therefore, it's unlikely that the regression result may have deviation because of heteroscedasticity. And the cross-section data are fine. 
Table 1. The results of Regression model

\begin{tabular}{|c|c|c|c|c|}
\hline \multirow{2}{*}{} & \multicolumn{2}{|c|}{ Model 1 } & \multicolumn{2}{c|}{ Model 2 } \\
\cline { 2 - 5 } & Coefficient & $\mathrm{p}$ value & Coefficient & $\mathrm{p}$ value \\
\hline$\beta_{1}$ & 0.0224 & 0.5206 & 0.2155 & 0.0192 \\
\hline$\beta_{2}$ & 0.0614 & 0.0000 & 0.2267 & 0.0031 \\
\hline$\beta_{3}$ & 0.0003 & 0.0006 & 0.3280 & 0.0054 \\
\hline$R^{2}$ & \multicolumn{2}{|c|}{0.4782} & \multicolumn{2}{c|}{0.5333} \\
\hline F-statistics & 20.4704 & \multicolumn{2}{c|}{0.0222} \\
\hline $\begin{array}{c}\text { Significance of } \\
\text { White testing }\end{array}$ & \multicolumn{2}{|c|}{0.0000} & \multicolumn{2}{c|}{} \\
\hline
\end{tabular}

As we can see from the table 1 , the model 1 goodness of fit is 0.4782 and the model 2 is 0.5333 , good fit of both. In model 1, the high significance of revenues and land indicate that they are notable factors for the acquisition of SME financing, however, asset factor is not significant. Asset coefficient is 0.0614 , which means every $10000 \mathrm{RMB}$ increase in the revenues, the SME financing will increase 614RMB. Land factor is the same, every increase in square meter will lead the financing increasing 3RMB.

It should be noted that revenues contributes more than land in model 1 while comparing the significance, which coincided with reality. Innovation of the credit technology have been propelled by most financial institutions in county areas. More emphasis on enterprises cash flow and more dynamic observation of the operation and management of enterprise because of these new technologies. Of course, land still plays an important role in collateral.

In model 2, the high significance of asset, revenues and land indicate that they are all key factors to SME financing so that enterprises could use the three elements to obtain loans from outside. But these factors' financing coefficients are all less than 1, indicating that it's hard for SME to acquire financing from outside. Hence the availability of SME financing is lacking of resilience. At least from the angle of financing, it's feeble for SME to deploy resources.

The financing coefficient of asset in model 2 is 0.2155 , much more significant than model 1 . What can illustrate from the discrepancy is that asset financing coefficient may be not the direct determinants to SME. That is to say, when borrowed from the financial institutions, SME found it unnecessary to consider asset first (the cash-ability of SME is bad), but asset may play a indirect part in SME financing. This effect manifested in that asset is the foundation for SME to establish, develop and obtain various resources from the external environment.

Revenue financing coefficient is 0.2267 , its $\mathrm{P}$ value is 0.0031 , exceeding asset and land at significance level. That means, revenue plays a more important role in SME financing, this is consistent with model 1. Owning to the financing coefficients are determined by both SME internal and external factors, the significance of revenue shows that lenders attach more importance to enterprises cash flow than other factors, which means investors' expectations and preferences are current earnings.

Land financing coefficient is 0.3280 , its $\mathrm{P}$ value is 0.0054 , greater than other two natural resources, therefore, land is a pivotal element to build enterprise financing. The fact means, at least in 2012, SME financing still relies on land factor. In spite of new micro-credit technology has made great progress in the credit markets, the land is still a momentous guarantee for financial institutions, working as a "hard currency".

The regression results analysis above reflect that SME' deploying capital from economic environment is in trouble. In other words, the worse allocating capital capability is, the lower availability of SME financing is, corresponding with SME' poor ability of dealing with shocks from external economic environment. From such a point of anticipation, it is after the shock that SME will nearly fail to resist, what's worse, the financing coefficients even get a further reduce. 


\section{Conclusions}

This paper presents an analysis of the availability of SME financing by establishing the concept of financing coefficient. Following the result of the estimated coefficients, the paper come to a conclusion that SME have difficulty in financing and the ability to obtain finance through their own resources endowment is weak. Moreover, the difficulty either comes from external or internal. It's more crucial for SME to improve the financing entitlement mapping system. Some of the monetary policies to promote the availability of SME financing may be inefficient. What's more, financing coefficients could offer financial institutions the help to survey SME financing conditions.

\section{References}

[1] Wan Fang, Tao Xiaohong. Publicness Issues of Microfinance: The Experience from Bangladesh and the Meso-deconstruction. International Economics and Trade Research, Volume 29, Issue 7 (2013), P. 102-112.

[2] Zheng Xia. Study on the Financing Mechanism of Small and Micro Enterprises Based on Policy Preferences : Taking Tianjin as Example. Journal of Central University of Finance and Economics, Volume 1 (2015), P. 41-46.

[3] Wang Xin. A Study on Internet Finance Helping Relieve SMEs Financing Constraints. Journal of Financial Research, Volume 9, Issue 423 (2015), P. 128-139.

[4] Li Mingxian, Luo Hehua. Credit Loss, Financing Incentive and the Development of Small and Micro Businesses. Journal of Yunan University of Finance and Economics, Volume 4 (2013), P. 142-148. 